\title{
The potential of large rafting objects to spread Lessepsian invaders: the case of a detached buoy
}

\author{
Angelina Ivkić $(\mathbb{D}) \cdot$ Jan Steger $(\mathbb{D}) \cdot$ Bella S. Galil $(\mathbb{D} \cdot$ Paolo G. Albano $\mathbb{C}$
}

Received: 27 September 2018/ Accepted: 19 March 2019/Published online: 29 March 2019

(C) The Author(s) 2019

\begin{abstract}
A diverse and abundant fouling community dominated by Lessepsian non-indigenous species was identified on a 13.5-m-long steel buoy stranded on the Israeli coast but originating from Port Said, at the Mediterranean entrance of the Suez Canal, Egypt. The molluscan community was sampled quantitatively by scraping. Three quarters of the individuals and more than half of the species were non-indigenous. Among the latter, a mytilid bivalve, Gregariella cf. ehrenbergi, was first recorded in the Mediterranean Sea on the basis of these samples, suggesting that the full consideration of all potential vectors can contribute to non-indigenous species detection. Large floating objects in coastal waters, such as buoys, are particularly suitable for colonization by Lessepsian species because hard substrates, and artificial ones in particular, are highly susceptible to the establishment of non-indigenous species. Moreover, their size and persistence enable the development of abundant and
\end{abstract}

A. Ivkić · J. Steger · P. G. Albano $(\bowtie)$

Department of Palaeontology, University of Vienna,

Althanstrasse 14, 1090 Vienna, Austria

e-mail:pgalbano@gmail.com

A. Ivkić

Faculty of Geosciences, Utrecht University, Princetonlaan

8a, 3584 CB Utrecht, The Netherlands

B. S. Galil

The Steinhardt Museum of Natural History, Israel National Center for Biodiversity Studies, Tel Aviv University, 69978 Tel Aviv, Israel mature fouling communities that can disseminate propagules as eggs and larvae over long distances and for extended periods if detached. This report highlights the potential for large rafting debris as a vector of the spread of non-indigenous biota within the Mediterranean Sea.

Keywords Anthropogenic debris · Rafting · Nonindigenous species · Introduction vectors · Fouling · Mediterranean Sea

\section{Introduction}

Floating marine litter is increasingly becoming an important vector of introduction and spread of nonindigenous species (NIS) (Kiessling et al. 2015). It may double or even triple the dispersal of marine organisms due to its high persistence (Barnes 2002) and open new introduction pathways (Hoeksema et al. 2012, 2015; Holmes et al. 2015; Carlton et al. 2017). The larger and longer-lasting floating objects have a greater potential as vectors for biological invasions because they likely host a more diverse fouling community and may traverse longer distances due to lower degradation and sinkage rates (Thiel and Gutow 2005; Goldstein et al. 2014). A major example is the dispersal of western Pacific species on rafting objects after the tsunami generated by the 2011 East Japan 
earthquake: 289 Japanese coastal species crossed the northern Pacific Ocean reaching the shores of North America and Hawai'i (Carlton et al. 2017). Some objects were as large as docks or fishing vessels, and able to carry tens of species per object.

In the Mediterranean Sea, the role of marine litter as a primary or secondary vector of species introductions has largely been neglected (Katsanevakis and Crocetta 2014); in the major recent assessments of pathways and vectors in Europe, it has been either lumped with others or not considered (Zenetos et al. 2012; Katsanevakis et al. 2013; Nunes et al. 2014; Galil et al. 2014). To improve our understanding of the role of marine litter as a vector of NIS dispersal, it is necessary to quantify the contribution of litter on their regional spread, determine which litter items are the main carriers, and identify the major donor and recipient areas (Rech et al. 2016).

One of the high-risk donor areas is certainly the Levantine Basin, the easternmost part of the Mediterranean Sea. The opening of the Suez Canal in 1869 triggered the Lessepsian invasion (Por 1978), and the recent Canal enlargement may turn out to have triggered the onset of a new wave of introductions (Galil et al. 2015, 2017). Any floating object in this region may be prone to the colonization by Lessepsian species and consequently may contribute to their transportation to other sectors of the basin.

Thus, the stranding of a 13.5-m-long steel buoy in Israel that was traced to originate from Port Said, Egypt, at the Mediterranean entrance to the Suez Canal, permitted the first examination of the role of large rafting debris in the Lessepsian invasion. During its ca 280-km-long journey, the buoy transported a diverse and abundant invertebrate assemblage dominated by NIS. To our knowledge, this is the first report of large rafting objects as vectors for Lessepsian invaders and our finding clearly demonstrates their potential in facilitating the secondary spread of Lessepsian NIS.

\section{Materials and methods}

In 2014, a 13.5-m-long steel buoy, originally moored at the entrance of the Suez Canal in Port Said, Egypt, got detached and stranded near Shefayim, Israel, from where it was subsequently transported to a dumping site in the close-by Herzliya Marina (Captain M. Solomon and A. Tzindr, pers. comm.). On 28 September 2016, we scraped the fouling community on the buoy from $0.1 \mathrm{~m}^{2}$ quadrats approximately every meter along a depth transect from the water line to its lowermost end (at originally $5.5 \mathrm{~m}$ depth) and, in addition, a quadrat in the interior of the buoy at ca $5.5 \mathrm{~m}$ depth (coded consecutively from Q1, water level, to Q7, in the interior). Q5 lacked fouling organisms and was omitted from consideration; the exterior of the buoy looked abraded, suggesting possible damage during transport with consequent loss of fouling organisms. Due to the long period elapsed between stranding and sampling, soft-bodied organisms were no longer present and thus we focused our research on mollusks, whose shells were abundant, and mostly still retained the dried tissues. The samples were sieved on $0.5 \mathrm{~mm}$ and $4 \mathrm{~mm}$ mesh and the retained mollusks identified to species. The samples will be deposited in the Natural History Museum Vienna and a voucher collection in the Steinhardt Museum of Natural History, Tel Aviv University.

We computed metrics and drew charts with the statistical programming environment $\mathrm{R}$ ( $\mathrm{R}$ Development Core Team 2008). We created the final graphical output with the program Inkscape.

\section{Results}

We identified 11 indigenous and 10 non-indigenous mollusk species (414 and 1294 individuals, respectively). Bivalves dominated the sampled molluscan community. Among the NIS, we found Gregariella cf. ehrenbergi (Issel, 1869), a species not previously recorded from the Mediterranean Sea (Steger et al. 2018). On the ground at the Herzliya Marina, next to the buoy, we found specimens of the non-indigenous intertidal gastropod Cellana rota (Gmelin, 1791). Fouling gastropods in most cases adhere with their foot and thus fall off once dead. In addition, we found few specimens of the crabs Eriphia verrucosa (Forskål, 1775) and the non-indigenous Sphaerozius nitidus Stimpson, 1858. The latter was reported from Port Said in a study on brachyuran crabs associated with marine fouling in Mediterranean Egyptian har- 
bors (Ibrahim and Ramadan 2016). Their presence suggests that the buoy arrived in the marina with still living fouling organisms. However, at the time of sampling, the original gastropod assemblage may have been partly lost and therefore be under-represented in our samples, potentially leading to an underestimation of NIS diversity and abundance for this taxonomic group. The buoy was also covered by many individuals of the non-indigenous Balanus trigonus (Darwin, 1854) and some specimens of Perforatus perforatus (Bruguière, 1789) as well as the non-indigenous Amphibalanus reticulatus (Utinomi, 1967).

In all quadrats, NIS were more diverse and abundant than native species, with the highest NIS diversity in Q2 $(-1 \mathrm{~m})$ and the greatest NIS abundance in Q1 (water line) (Fig. 1). The most abundant NIS were Brachidontes pharaonis (P. Fischer, 1870) and Malleus regula (Forsskål in Niebuhr, 1775) with 746 and 297 individuals, respectively (Table 1). Modiolus cf. barbatus and Striarca lactea (Linnaeus, 1758) were the most abundant native species with 241 and 62 individuals, respectively (Table 1). It is worth mentioning that the identity of the mytilid bivalve Modiolus cf. barbatus (Linnaeus, 1758) is uncertain: a similar species is known from the Red Sea (Oliver 1992) but the taxonomic knowledge of the genus in the Indo-Pacific province is too poor for a definite identification, especially at the sub-adult stage of most of our specimens. Because of its abundance, however, if this species would prove to be a Red Sea Modiolus, most metrics of non-indigenous species diversity and abundance would increase considerably. Dendostrea cf. folium (Linnaeus, 1758) is also tentatively identified due to the poor taxonomic knowledge of the group (Crocetta et al. 2015), but it is clearly not a native species. In most quadrats, natives were more abundant in the smaller $(0.5-4 \mathrm{~mm})$ than in the larger shell size fraction $(>4 \mathrm{~mm})$ (Table 2). The one exception was Q2, a particularly poor sample with only 13 individuals. Overall, species richness did not differ between the size fractions.

\section{Discussion}

The rich sessile fouling community on the buoy was at an advanced successional stage, as the presence of adult specimens of the bivalves Brachidontes pharaonis in Q1 and Malleus regula in Q7 suggests (Astudillo et al. 2009). Some specimens of Pinctada imbricata radiata are more than $10 \mathrm{~cm}$ long and thus more than 6 years old (Narayanan and Michael 1968). Their size, as well as the large size of some specimens of Chama pacifica and Malleus regula, suggest that this community developed while the buoy was still moored at Port Said.

We also detected a new NIS on the buoy, the mytilid Gregariella cf. ehrenbergi. This species has a complex taxonomic status and cryptic habitat (Steger et al. 2018) which may cause significant time lags in first detection (Crooks 2005; Albano et al. 2018). Therefore, we cannot determine whether this is truly a recent arrival, but our study demonstrates that the full consideration of all potential vectors can contribute to NIS detection.

Steel buoys are particularly suitable for the colonization by sessile and motile NIS because hard substrates are highly susceptible to their establishment and, once detached from their mooring, are likely to serve as raft for their fouling community (Miller 1968; Kerckhof and Cattrijsse 2001; Wasson et al. 2005; Lim et al. 2009; Nawrot et al. 2015; Simpson et al. 2016). Moreover, artificial substrates facilitate NIS establishment (Bulleri and Airoldi 2005; Glasby et al. 2007; Bulleri and Chapman 2010) because of weaker competitive interactions, as predicted by the biotic resistance hypothesis (Elton 1958), or because of reduced mortality due to predation, as predicted by the enemy release hypothesis (Keane and Crawley 2002) and experimentally tested (Dumont et al. 2011; Rogers et al. 2016). Indeed, $75 \%$ of the individuals on the buoy were identified as NIS. The NIS dominance was even more prominent in the larger size fraction $(>4 \mathrm{~mm})$, likely a consequence of the larger average size of the Red Sea species pool (Nawrot et al. 2017).

Marine litter, in general, has rarely been discussed as a vector of primary or secondary NIS introduction in the Mediterranean Sea and, to the best of our knowledge, this is the first report of Lessepsian NIS transported on a detached buoy. The Mediterranean Sea hosts a great number of large floating objects such as navigational buoys, components of aquaculture plants and harbor pontoons, where rich fouling communities can develop (Kerckhof and Cattrijsse 


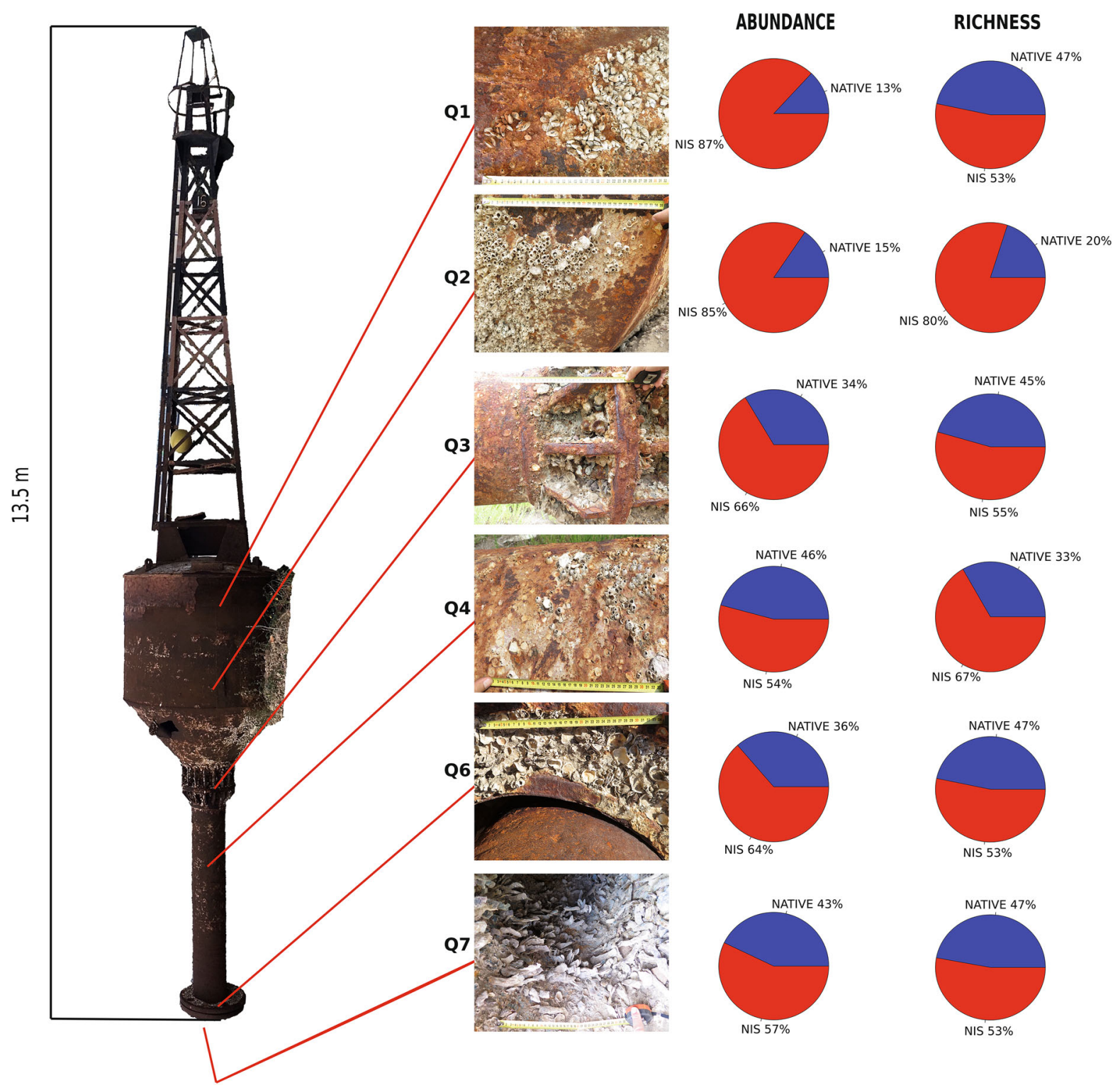

Fig. 1 Position of the sampled quadrats on the buoy and share of native versus non-indigenous species (NIS) abundance and richness (in \%). Photos were shot with the buoy laying horizontally. The location of Q1 represents the original water

2001; Lim et al. 2009; Rech et al. 2018). If such large objects get detached, they may serve as a vector of NIS spread during rafting because under suitable conditions mature individuals may release eggs and larvae en route (Lockwood et al. 2005, 2009; Simberloff 2009). line. Q5 was located between Q4 and Q6 but did not contain mollusks and is therefore omitted. Q7 is situated in the interior of the buoy. Abundance and species richness of NIS (in red) were higher than of native species (in blue) at all depths

Therefore, we propose that large rafting objects should be fully considered as vectors of biological invasions in the Mediterranean Sea. 
Table 1 Species abundance in each quadrat (Q5 did not contain any mollusks)

\begin{tabular}{|c|c|c|c|c|c|c|c|c|c|}
\hline Class & Family & Genus & Status & Q1 & Q2 & Q3 & Q4 & Q6 & Q7 \\
\hline Gastropoda & Cerithiopsidae & Cerithiopsis tenthrenois (Melvill, 1896) & NIS & 0 & 0 & 0 & 0 & 0 & 2 \\
\hline Gastropoda & Rissoidae & Crisilla semistriata (Montagu, 1808) & Native & 0 & 0 & 0 & 0 & 0 & 1 \\
\hline Bivalvia & Arcidae & Arca noae (Linnaeus, 1758) & Native & 3 & 0 & 0 & 0 & 1 & 0 \\
\hline Bivalvia & Noetiidae & Striarca lactea (Linnaeus, 1758) & Native & 2 & 2 & 5 & 1 & 29 & 23 \\
\hline Bivalvia & Mytilidae & Gregariella cf. ehrenbergi (Issel, 1869) & NIS & 12 & 0 & 6 & 2 & 45 & 18 \\
\hline Bivalvia & Mytilidae & Musculus subpictus (Cantraine, 1835) & Native & 0 & 0 & 0 & 0 & 0 & 2 \\
\hline Bivalvia & Mytilidae & Musculus costulatus (Risso, 1826) & Native & 1 & 0 & 0 & 0 & 0 & 0 \\
\hline Bivalvia & Mytilidae & Lithophaga lithophaga (Linnaeus, 1758) & Native & 0 & 0 & 1 & 0 & 0 & 4 \\
\hline Bivalvia & Mytilidae & Modiolus cf. barbatus (Linnaeus, 1758) & Native & 83 & 0 & 49 & 7 & 23 & 79 \\
\hline Bivalvia & Mytilidae & Arcuatula senhousia (Benson, 1842) & NIS & 1 & 0 & 0 & 0 & 0 & 0 \\
\hline Bivalvia & Mytilidae & Brachidontes pharaonis (P. Fischer, 1870) & NIS & 708 & 4 & 15 & 1 & 8 & 10 \\
\hline Bivalvia & Mytilidae & Septifer cumingii (Récluz, 1848) & NIS & 37 & 2 & 4 & 3 & 20 & 15 \\
\hline Bivalvia & Mytilidae & Mytilaster cf. minimus (Poli, 1795) & Native & 2 & 0 & 0 & 0 & 1 & 0 \\
\hline Bivalvia & Pteriidae & Pinctada imbricata radiata (Leach, 1814) & NIS & 3 & 0 & 0 & 0 & 2 & 5 \\
\hline Bivalvia & Ostreidae & Ostrea edulis (Linnaeus, 1758) & Native & 27 & 0 & 7 & 1 & 13 & 1 \\
\hline Bivalvia & Ostreidae & Dendostrea cf. folium (Linnaeus, 1758) & NIS & 5 & 4 & 28 & 1 & 1 & 7 \\
\hline Bivalvia & Malleidae & Malleus regula (Forsskål in Niebuhr, 1775) & NIS & 58 & 1 & 70 & 2 & 66 & 100 \\
\hline Bivalvia & Chamidae & Chama pacifica (Broderip, 1835) & NIS & 3 & 0 & 6 & 1 & 5 & 10 \\
\hline Bivalvia & Myidae & Sphenia binghami (Turton, 1822) & Native & 7 & 0 & 4 & 0 & 16 & 15 \\
\hline Bivalvia & Gastrochaenidae & Cucurbitula cymbium (Spengler, 1783) & NIS & 0 & 0 & 0 & 0 & 2 & 1 \\
\hline Bivalvia & Gastrochaenidae & Rocellaria dubia (Pennant, 1777) & Native & 0 & 0 & 0 & 0 & 3 & 1 \\
\hline
\end{tabular}

The most abundant non-indigenous species (NIS) and native species in each quadrat are marked in bold

Table 2 Abundance and species richness of nonindigenous species (NIS) and native species in the two size fractions

\begin{tabular}{lllllll}
\hline \multirow{2}{*}{ Quadrat } & Mesh size & \multicolumn{2}{l}{ Abundance } & & \multicolumn{2}{l}{ Species richness } \\
\cline { 3 - 4 } \cline { 6 - 7 } & & NIS & Native & & NIS & Native \\
\hline Q1 & $0.5-4 \mathrm{~mm}$ & $201(73 \%)$ & $75(27 \%)$ & & $6(50 \%)$ & $6(50 \%)$ \\
& $>4 \mathrm{~mm}$ & $624(93 \%)$ & $49(7 \%)$ & & $7(58 \%)$ & $5(42 \%)$ \\
Q2 & $0.5-4 \mathrm{~mm}$ & $3(100 \%)$ & $0(0 \%)$ & & $1(100 \%)$ & $0(0 \%)$ \\
& $>4 \mathrm{~mm}$ & $8(80 \%)$ & $2(20 \%)$ & & $4(80 \%)$ & $1(20 \%)$ \\
Q3 & $0.5-4 \mathrm{~mm}$ & $29(37 \%)$ & $50(63 \%)$ & & $5(56 \%)$ & $4(44 \%)$ \\
& $>4 \mathrm{~mm}$ & $98(87 \%)$ & $15(13 \%)$ & & $4(57 \%)$ & $3(43 \%)$ \\
Q4 & $0.5-4 \mathrm{~mm}$ & $4(36 \%)$ & $7(64 \%)$ & & $3(75 \%)$ & $1(25 \%)$ \\
& $>4 \mathrm{~mm}$ & $6(75 \%)$ & $2(25 \%)$ & & $4(67 \%)$ & $2(33 \%)$ \\
Q6 & $0.5-4 \mathrm{~mm}$ & $81(57 \%)$ & $62(43 \%)$ & & $7(54 \%)$ & $6(46 \%)$ \\
& $>4 \mathrm{~mm}$ & $67(74 \%)$ & $23(26 \%)$ & & $24(86 \%)$ & $4(14 \%)$ \\
Q7 & $0.5-4 \mathrm{~mm}$ & $75(38 \%)$ & $124(62 \%)$ & & $8(53 \%)$ & $7(47 \%)$ \\
& $>4 \mathrm{~mm}$ & $93(98 \%)$ & $2(2 \%)$ & & $5(71 \%)$ & $2(29 \%)$ \\
\hline
\end{tabular}

Acknowledgements Sampling in Israel was conducted in the framework of the project "Historical ecology of Lessepsian migration" funded by the Austrian Science Fund (FWF) P28983-B29 (PI: P. G. Albano). AI was supported by an
ERASMUS + traineeship. We are indebted to Martin Zuschin for his support all along the planning and running of the project. We thank Captain Michael Solomon, Senior Marine Surveyor, Shipping and Ports Administration and Amir Tzindr, Harbour 
Master, Herzliya Marina for information on the origin and location of the stranded buoy. Beata Dunne copyedited the manuscript final version. Graham Oliver and Francis Kerckhof offered useful suggestions on the identification of bivalves and barnacles, respectively. Furthermore, we thank Francesca Sangiorgi for additional support and supervision. Two anonymous reviewers provided useful suggestions on a first version of the ms. Open access funding provided by Austrian Science Fund (FWF).

Open Access This article is distributed under the terms of the Creative Commons Attribution 4.0 International License (http:// creativecommons.org/licenses/by/4.0/), which permits unrestricted use, distribution, and reproduction in any medium, provided you give appropriate credit to the original author(s) and the source, provide a link to the Creative Commons license, and indicate if changes were made.

\section{References}

Albano PG, Gallmetzer I, Haselmair A, Tomašových A, Stachowitsch M, Zuschin M (2018) Historical ecology of a biological invasion: the interplay of eutrophication and pollution determines time lags in establishment and detection. Biol Invasions 20:1417-1430. https://doi.org/ 10.1007/s10530-017-1634-7

Astudillo JC, Bravo M, Dumont CP, Thiel M (2009) Detached aquaculture buoys in the SE pacific: potential dispersal vehicles for associated organisms. Aquat Biol 5:219-231. https://doi.org/10.3354/ab00151

Barnes DKA (2002) Invasions by marine life on plastic debris. Nature 416:808-809. https://doi.org/10.1038/416808a

Bulleri F, Airoldi L (2005) Artificial marine structures facilitate the spread of a non-indigenous green alga, Codium fragile ssp. tomentosoides, in the north Adriatic Sea. J Appl Ecol 42:1063-1072. https://doi.org/10.1111/j.1365-2664.2005. 01096.x

Bulleri F, Chapman MG (2010) The introduction of coastal infrastructure as a driver of change in marine environments. J Appl Ecol 47:26-35. https://doi.org/10.1111/j. 1365-2664.2009.01751.x

Carlton JT, Chapman JW, Geller JB et al (2017) Tsunami-driven rafting: transoceanic species dispersal and implications for marine biogeography. Science 357:1402-1406. https://doi. org/10.1126/science.aao1498

Crocetta F, Mariottini P, Salvi D, Oliverio M (2015) Does GenBank provide a reliable DNA barcode reference to identify small alien oysters invading the Mediterranean Sea? J Mar Biol Assoc U K 95:111-122. https://doi.org/10. $1017 / \mathrm{S} 0025315414001027$

Crooks JA (2005) Lag times and exotic species: the ecology and management of biological invasions in slow-motion. Ecoscience 12:316-329. https://doi.org/10.2980/i11956860-12-3-316.1

Dumont CP, Harris LG, Gaymer CF (2011) Anthropogenic structures as a spatial refuge from predation for the invasive bryozoan Bugula neritina. Mar Ecol Prog Ser 427:95-103. https://doi.org/10.3354/meps09040
Elton CS (1958) The ecology of invasions by animals and plants. Methuen, London

Galil BS, Marchini A, Occhipinti-Ambrogi A, Minchin D, Narščius A, Ojaveer H, Olenin S (2014) International arrivals: widespread bioinvasions in European Seas. Ethol Ecol Evol 26:152-171. https://doi.org/10.1080/03949370. 2014.897651

Galil BS, Boero F, Campbell ML et al (2015) 'Double trouble': the expansion of the Suez Canal and marine bioinvasions in the Mediterranean Sea. Biol Invasions 17:973-976. https:// doi.org/10.1007/s10530-014-0778-y

Galil B, Marchini A, Occhipinti-Ambrogi A, Ojaveer H (2017) The enlargement of the Suez Canal-Erythraean introductions and management challenges. Manag Biol Invasions 8:141-152. https://doi.org/10.3391/mbi.2017.8.2.02

Glasby TM, Connell SD, Holloway MG, Hewitt CL (2007) Nonindigenous biota on artificial structures: Could habitat creation facilitate biological invasions? Mar Biol 151:887-895. https://doi.org/10.1007/s00227-006-0552-5

Goldstein MC, Carson HS, Eriksen M (2014) Relationship of diversity and habitat area in North Pacific plastic-associated rafting communities. Mar Biol 161:1441-1453. https://doi.org/10.1007/s00227-014-2432-8

Hoeksema B, Roos P, Cadée G (2012) Trans-Atlantic rafting by the brooding reef coral Favia fragum on man-made flotsam. Mar Ecol Prog Ser 445:209-218. https://doi.org/10. 3354/meps09460

Hoeksema B, Roos P, Cadée G (2015) Trans-Atlantic rafting by the brooding reef coral Favia fragum on man-made flotsam. Corrigendum. Mar Ecol Prog Ser 451:209-218. https://doi.org/10.3354/meps09460

Holmes AM, Oliver PG, Trewhella S, Hill R, Quigley DTG (2015) Trans-Atlantic rafting of inshore Mollusca on macro-litter: american molluscs on British and Irish shores, new records. J Conchol 42:1-9

Ibrahim KMA, Ramadan SE (2016) Brachyuran crabs associated with marine fouling from Egyptian Mediterranean harbors. Rapport Commission Internationale Mer Méditerranée 41:421

Katsanevakis S, Crocetta F (2014) Pathways of introduction of marine alien species in European waters and the Mediterranean-a possible undermined role of marine litter. In: Briand F (ed) Marine litter in the Mediterranean and Black Seas. CIESM Publisher, Monaco, p 180

Katsanevakis S, Zenetos A, Belchior C, Cardoso AC (2013) Invading European Seas: assessing pathways of introduction of marine aliens. Ocean Coast Manag 76:64-74. https://doi.org/10.1016/j.ocecoaman.2013.02.024

Keane R, Crawley MJ (2002) Exotic plant invasions and the enemy release hypothesis. Trends Ecol Evol 17:164-170. https://doi.org/10.1016/S0169-5347(02)02499-0

Kerckhof F, Cattrijsse A (2001) Exotic Cirripedia (Balanomorpha) from buoys off the Belgian coast. Senckenb Marit 31:245. https://doi.org/10.1007/ BF03043033

Kiessling T, Gutow L, Thiel M (2015) Marine litter as habitat and dispersal vector. In: Bergmann M, Gutow L, Klages M (eds) Marine anthropogenic litter. Springer, Cham, pp 141-181 
Lim S-C, de Voogd NJ, Tan K-S (2009) Fouling sponges (Porifera) on navigation buoys from Singapore waters. Raffles Bull Zool 22(suppl.):41-58

Lockwood JL, Cassey P, Blackburn T (2005) The role of propagule pressure in explaining species invasions. Trends Ecol Evol 20:223-228. https://doi.org/10.1016/j.tree.2005. 02.004

Lockwood JL, Cassey P, Blackburn TM (2009) The more you introduce the more you get: the role of colonization pressure and propagule pressure in invasion ecology. Divers Distrib 15:904-910. https://doi.org/10.1111/j.1472-4642. 2009.00594.x

Miller MA (1968) Isopoda and Tanaidacea from Buoys in coastal waters of the Contintental United States, Hawaii, and the Bahamas (Crustacea). Proc U S Natl Mus 125:1-53

Narayanan KR, Michael MS (1968) On the relation between age and linear measurements of the pearl oyster Pinctada vulgaris (Schumacher) of the Gulf of Kutch. J Bombay Nat Hist Soc 65:444-452

Nawrot R, Chattopadhyay D, Zuschin M (2015) What guides invasion success? Ecological correlates of arrival, establishment and spread of Red Sea bivalves in the Mediterranean Sea. Divers Distrib 21:1075-1086. https://doi.org/ 10.1111/ddi.12348

Nawrot R, Albano PG, Chattopadhyay D, Zuschin M (2017) Climate change and body size shift in Mediterranean bivalve assemblages: unexpected role of biological invasions. Proc R Soc B Biol Sci 284:20170357. https://doi.org/ 10.1098/rspb.2017.0357

Nunes AL, Katsanevakis S, Zenetos A, Cardoso AC (2014) Gateways to alien invasions in the European seas. Aquat Invasions 9:133-144. https://doi.org/10.3391/ai.2014.9.2. 02

Oliver PG (1992) Bivalved seashells of the Red Sea. Verlag Christa Hemmen, Wiesbaden

Por FD (1978) Lessepsian migration: the influx of Red Sea biota into the Mediterranean by way of the Suez Canal. Springer, Berlin

R Development Core Team (2008) R: a language and environment for statistical computing. R Foundation for Statistical Computing, Vienna
Rech S, Borrell Y, García-Vazquez E (2016) Marine litter as a vector for non-native species: what we need to know. Mar Pollut Bull 113:40-43. https://doi.org/10.1016/j.marpolbul. 2016.08.032

Rech S, Salmina S, Borrell Pichs YJ, García-Vazquez E (2018) Dispersal of alien invasive species on anthropogenic litter from European mariculture areas. Mar Pollut Bull 131: 10-16. https://doi.org/10.1016/j.marpolbul.2018.03.038

Rogers TL, Byrnes JE, Stachowicz JJ (2016) Native predators limit invasion of benthic invertebrate communities in Bodega Harbor, California, USA. Mar Ecol Prog Ser 545:161-173. https://doi.org/10.3354/meps11611

Simberloff D (2009) The role of propagule pressure in biological invasions. Annu Rev Ecol Evol Syst 40:81-102. https://doi.org/10.1146/annurev.ecolsys.110308.120304

Simpson TS, Wernberg T, McDonald JI (2016) Distribution and localised effects of the invasive Ascidian Didemnum perlucidum (Monniot 1983) in an Urban Estuary. PLoS ONE 11:e0154201. https://doi.org/10.1371/journal.pone.0154201

Steger J, Stockinger M, Ivkić A, Galil BS, Albano PG (2018) New records of non-indigenous molluscs from the eastern Mediterranean Sea. BioInvasions Rec 7:245-257. https:// doi.org/10.3391/bir.2018.7.3.05

Thiel M, Gutow L (2005) The ecology of rafting in the marine environment. I. The floating substrata. Oceanogr Mar Biol 42:181-263

Wasson K, Fenn K, Pearse JS (2005) Habitat differences in marine invasions of central California. Biol Invasions 7:935-948. https://doi.org/10.1007/s10530-004-2995-2

Zenetos A, Gofas S, Morri C et al (2012) Alien species in the Mediterranean Sea by 2012. A contribution to the application of European Union's Marine Strategy Framework Directive (MSFD). Part 2. Introduction trends and pathways. Mediterr Mar Sci 13:328-352. https://doi.org/10. 12681/mms.327

Publisher's Note Springer Nature remains neutral with regard to jurisdictional claims in published maps and institutional affiliations. 